University of Nebraska - Lincoln

DigitalCommons@University of Nebraska - Lincoln

Faculty Publications: Department of Entomology

October 1990

\title{
Insecticide Toxicity, Synergism, and Resistance in the German Cockroach (Dictyoptera: Blattellidae)
}

Jeffrey G. Scott

Comstock Hall, Cornell University, Ithaca, New York

Donald C. Cochran

Comstock Hall, Cornell University, Ithaca, New York

Blair Siegfried

University of Nebraska-Lincoln, bsiegfried1@ufl.edu

Follow this and additional works at: https://digitalcommons.unl.edu/entomologyfacpub

Part of the Entomology Commons

Scott, Jeffrey G.; Cochran, Donald C.; and Siegfried, Blair, "Insecticide Toxicity, Synergism, and Resistance in the German Cockroach (Dictyoptera: Blattellidae)" (1990). Faculty Publications: Department of Entomology. 56.

https://digitalcommons.unl.edu/entomologyfacpub/56

This Article is brought to you for free and open access by the Entomology, Department of at DigitalCommons@University of Nebraska - Lincoln. It has been accepted for inclusion in Faculty Publications: Department of Entomology by an authorized administrator of DigitalCommons@University of Nebraska - Lincoln. 


\title{
Insecticide Toxicity, Synergism, and Resistance in the German Cockroach (Dictyoptera: Blattellidae)
}

\author{
JEFFREY G. SCOTT, ${ }^{1}$ DONALD G. COCHRAN, ${ }^{2}$ \\ AND BLAIR D. SIEGFRIED \\ Department of Entomology, Comstock Hall, Cornell University, \\ Ithaca, New York 14853
}

\begin{abstract}
J. Econ. Entomol. 83(5): 1698-1703 (1990)
ABSTRACT The toxicity of, synergism of, and resistance to insecticides in four strains of German cockroach, Blattella germanica (L.), were investigated. Toxicity of nine insecticides by topical application to the susceptible strain varied $>2,000$-fold, with deltamethrin $\left(L_{50}\right.$ $=0.004 \mu \mathrm{g}$ per cockroach) and malathion $\left(\mathrm{LD}_{50}=8.4 \mu \mathrm{g}\right.$ per cockroach) being the most and least toxic, respectively. Resistance to pyrethrins (9.5-fold) in the Kenly strain was unaffected by the synergists piperonyl butoxide (PBO) or S,S,S-tributylphosphorotrithioate (DEF), suggesting that metabolism is not involved in this case. Malathion resistance in the Rutgers strain was suppressible with $\mathrm{PBO}$, implicating oxidative metabolism as a resistance mechanism. The Ectiban-R strain was resistant to all the pyrethroids tested, and cypermethrin resistance was not suppressible with PBO or DEF. These findings support results of previous studies that indicated this strain has a $k d r$-like mechanism. Bendiocarb resistance in both the Kenly and Rutgers strains was partially suppressed by either PBO or DEF, suggesting that oxidative and hydrolytic metabolism are involved in the resistance. Trends between the effects of the synergists on the susceptible versus resistant strains are discussed.
\end{abstract}

KEY WORDS Insecta, resistance, synergist, cockroach

INSECTICIDE RESISTANCE in the German cockroach, Blattella germanica, is a substantial problem that contributes to control problems in many areas (Rust \& Reierson 1978; Cochran 1982, 1989). German cockroaches have developed resistance to a wide range of insecticides including organochlorine, organophosphate, and pyrethroid insecticides. Although efforts at monitoring for resistance in field-collected strains of German cockroaches have been successful (e.g., Cochran 1989), very little information is available on the mechanisms of resistance in this species. Such information is critically needed if we are to design resistance management programs intelligently.

This study was undertaken to characterize the resistance spectrum in three strains of German cockroach variously resistant to insecticides and to gain preliminary information on the mechanisms of resistance in these strains with the use of synergists.

\section{Materials and Methods}

Cockroach Strains. Four strains of German cockroach were used in this study. (1) CSMA is a susceptible strain obtained from F. Matsumura, Michigan State University, in 1986, which has been reared continuously without selection pressure. (2)

\footnotetext{
To whom correspondence should be addressed

'Department of Entomology, Virginia Polytechnic Institute and State University, Blacksburg, Va. 24061.
}

Ectiban-R had been selected (by J.G.S.) from the DDT-selected VPIDLS strain (Scott \& Matsumura 1981, 1983) during 1980-1981 as described previously (Scott \& Matsumura 1983) with permethrin concentrations of $0.77 \mu \mathrm{g}$ per $\mathrm{cm}^{2}$ for $10 \mathrm{~h}, 0.77 \mu \mathrm{g}$ per $\mathrm{cm}^{2}$ for $24 \mathrm{~h}, 1.9 \mu \mathrm{g}$ per $\mathrm{cm}^{2}$ for $24 \mathrm{~h}$, and 9.6 $\mu \mathrm{g}$ per $\mathrm{cm}^{2}$ for $28 \mathrm{~d}$ for the first-generation males, first-generation females, second generation (both sexes), and third generation (both sexes), respectively. Ectiban-R was obtained from F. Matsumura in 1986; during 1987-1988, the strain was selected twice with permethrin at a concentration of $3.1 \mu \mathrm{g}$ per $\mathrm{cm}^{2}$ for $24 \mathrm{~h}$. The parental VPIDLS strain has an insensitive nervous system ( $k d r$-type resistance mechanism) conferring resistance to DDT and pyrethroid insecticides (Scott \& Matsumura 1981, 1983). This strain is genetically similar to CSMA (except for the resistance gene) due to repeated backcrossing and selection (Telford \& Matsumura 1970). The VPIDLS strain slowly reverts to susceptibility in the absence of selection pressure. However, there has been no apparent loss of resistance in the Ectiban-R strain after the last selections in 1988. (3) Kenly was collected from a house in Kenly, N.C., in 1984 and has been reported to have resistance to pyrethrins and bendiocarb that can be suppressed with piperonyl butoxide (Cochran 1987). The Kenly strain was obtained (from D.G.C.) in 1986 and was selected in 1987 with $7.7 \mu \mathrm{g}$ of bendiocarb per $\mathrm{cm}^{2}$ for $24 \mathrm{~h}$. (4) Rutgers was collected from a cafeteria in New Brunswick, N.J., in 1984. The Rutgers strain was obtained (from 
D.G.C.) in 1986 and was selected in 1987 at a concentration of $3.8 \mu \mathrm{g}$ malathion per $\mathrm{cm}^{2}$ for 24 h. The Kenly and Rutgers strains arose from a random collection not connected with a particular problem area. Accurate records of treatment before collection were impossible to obtain.

All cockroach colonies were reared at $29^{\circ} \mathrm{C}$ with a 50\% RH and a photoperiod of 12:12 (L:D). Colonies were fed Purina dog chow and water ad lib. and maintained in cheesecloth-covered plastic or glass containers in which the rim was coated with Fluon ADI (Northern Products, Inc., Woonsocket, R.I.) or Tree Tanglefoot (The Tanglefoot Company, Grand Rapids, Mich.).

Chemicals and Insecticides. The following insecticides were used: bendiocarb (76\% [AI]; BFC Chemicals, Wilmington, Del.), chlorpyrifos (99\% [AI]; Dow Chemical Company, Midland, Mich.), cypermethrin $(94.6 \%$ [AI]; ICI Americas, Wilmington, Del), deltamethrin (>99\% [AI]; Roussel Uclaf, Paris), fenfluthrin (1-R-trans isomer, Bayer Ag, Bayerwerk, Federal Republic of Germany), malathion (94.2\% [AI]; American Cyanamid Company, Princeton, N.J.), propoxur (94.0\% [AI]; source unknown), permethrin (94.0\% [AI]; Cooper Animal Health, Kansas City, Kans.), and pyrethrins (50.79\% [AI]; Fairfield American Corporation, Newark, N.J.). The cytochrome $\mathrm{P}-450$ monooxygenase inhibitor piperonyl butoxide (PBO) (>95\% [AI]; Chemical Dynamics Corp., South Plainfield, N.J.) and the hydrolytic inhibitor DEF (S,S,S-tributylphosphorotrithioate; Chem Service Inc., West Chester, $\mathrm{Pa}$.) were used as synergists.

Bioassay Methods. Most bioassays were done by topical application to the abdomen as previously described (Scott \& Matsumura 1981) with the following modifications: the insecticide was delivered in $0.5 \mu \mathrm{l}$ acetone, and 10 male cockroaches were tested per dose. All bioassays had at least three doses that caused $>0 \%$ and $<100 \%$ mortality. The synergists $\mathrm{PBO}$ and DEF were applied in a $0.5 \mu \mathrm{l}$ drop to the abdominal sternum $\mathrm{l} h$ before insecticide application at doses of $100^{\circ} \mu \mathrm{g}$ and $30 \mu \mathrm{g}$ per cockroach, respectively. Mortality was evaluated $24 \mathrm{~h}$ after insecticide application. Data were analyzed by probit analysis (Raymond 1985). Some experiments were done by exposing large nymphs to a residue of a single dose of insecticide or insecticide + synergist, and observing nymphs over time as described by Cochran (1989).

\section{Results and Discussion}

The toxicities of nine insecticides alone or with synergist (tested by topical application) to the susceptible (CSMA) strain of German cockroaches are shown in Table $1 . L D_{50}$ 's ranged from $0.004 \mu \mathrm{g}$ per cockroach for the most toxic insecticide (deltamethrin) to $8.4 \mu \mathrm{g}$ per cockroach for the least toxic insecticide (malathion). The cytochrome P-450 monooxygenase inhibitor $\mathrm{PBO}$ caused $>30$-fold synergism for pyrethrins and a $>10$-fold synergism

\section{Insecticide}

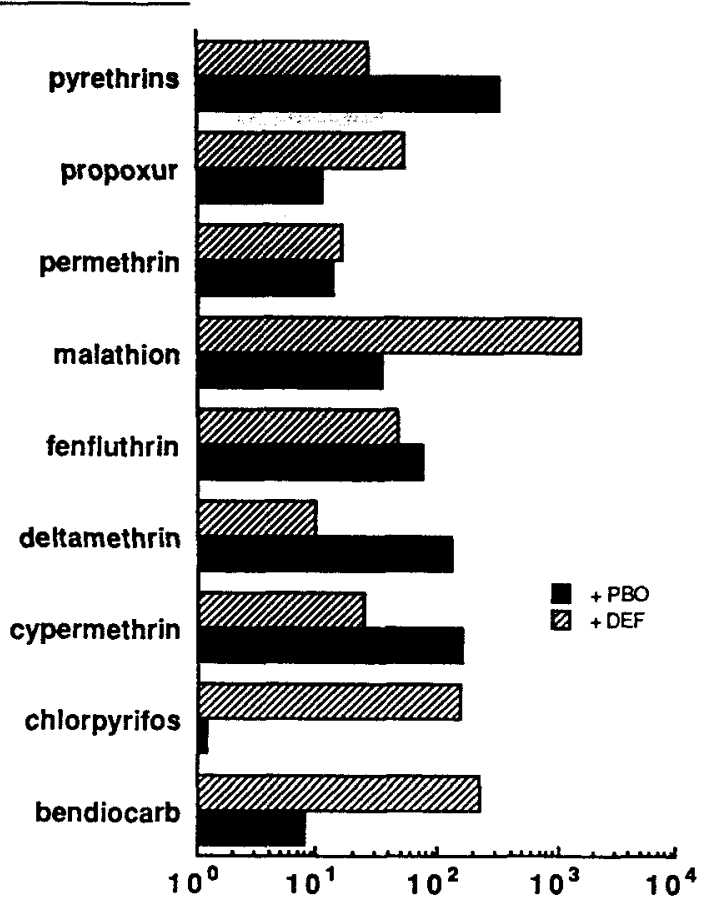

\section{Synergistic Ratio $\times 10$}

Fig. 1. Synergistic ratio of PBO or DEF on 10 insecticides tested by topical application on the susceptible strain.

for cypermethrin and deltamethrin at the $L D_{50}$ (Fig. 1). This result differs from those of a previous study in which synergism of pyrethrins was not detected with simultaneous exposure to insecticide and $\mathrm{PBO}$ in a fixed-dose, time-variable residue bioassay (Cochran 1987). This difference may have occurred because immobilization of cockroaches with the concentration of pyrethrins used for the $\mathrm{LT}_{50}$ assay was so rapid $(\approx 10 \mathrm{~min})$ that metabolism was not important in the poisoning process (Sawicki 1962, Ford \& Pert 1974, Scott \& Matsumura 1983, Scott \& Georghiou 1984). Alternatively, the two methods of exposure could affect different metabolic sites. PBO also decreased the toxicity of chlorpyrifos 8 -fold, probably by blocking the monooxygenase-mediated activation of chlorpyrifos to chlorpyrifos-oxon. The enzymatic hydrolysis inhibitor DEF caused a $>10$-fold synergism (Fig. 1) to three insecticides: bendiocarb, chlorpyrifos, and malathion. The level of synergism to malathion by DEF was quite remarkable (150-fold), suggesting that hydrolytic metabolism of malathion is quite high even in susceptible cockroaches. Such high metabolism is probably one reason why malathion was the least toxic insecticide that we tested against the susceptible strain.

The toxicities of seven insecticides to three re- 
Table 1. Toxicity of nine insecticides with and without synergist to a susceptible (CSMA) strain of German cockroach by topical application

\begin{tabular}{|c|c|c|c|c|c|c|c|c|c|}
\hline \multirow[b]{2}{*}{ Insecticide } & \multicolumn{3}{|c|}{ Insecticide alone } & \multicolumn{3}{|c|}{ Insecticide + PBO } & \multicolumn{3}{|c|}{ Insecticide + DEF } \\
\hline & $n$ & $\begin{array}{l}\text { Slope } \\
\text { (士SE) }\end{array}$ & $\begin{array}{c}\mathrm{LD}_{50}{ }^{a} \\
(95 \% \mathrm{CI})\end{array}$ & $n$ & $\begin{array}{l}\text { Slope } \\
( \pm \text { SE) }\end{array}$ & $\begin{array}{c}\mathrm{LD}_{50^{a}} \\
(95 \% \mathrm{CI})\end{array}$ & $n$ & $\begin{array}{l}\text { Slope } \\
( \pm \text { SE) }\end{array}$ & $\begin{array}{c}L_{50^{a}} \\
(95 \% \mathrm{Cl})\end{array}$ \\
\hline Bendiocarb & 150 & $\begin{array}{c}2.3 \\
(0.4)\end{array}$ & $\begin{array}{c}0.36 \\
(0.27-0.49)\end{array}$ & 120 & $\begin{array}{c}2.0 \\
(0.4)\end{array}$ & $\begin{array}{c}0.45 \\
(0.32-0.68)\end{array}$ & 165 & $\begin{array}{c}3.1 \\
(0.6)\end{array}$ & $\begin{array}{c}0.016 \\
(0.013-0.020)\end{array}$ \\
\hline Chlorpyrifos & 150 & $\begin{array}{l}4.1 \\
(0.7)\end{array}$ & $\begin{array}{c}0.26 \\
(0.22-0.30)\end{array}$ & 120 & $\begin{array}{c}4.1 \\
(0.7)\end{array}$ & $\begin{array}{l}2.1 \\
(1.7-2.6)\end{array}$ & 180 & $\begin{array}{c}4.8 \\
(0.8)\end{array}$ & $\begin{array}{c}0.017 \\
(0.013-0.020)\end{array}$ \\
\hline Cypermethrin & 120 & $\begin{array}{c}2.7 \\
(0.5)\end{array}$ & $\begin{array}{c}0.049 \\
(0.038-0.069)\end{array}$ & 120 & $\begin{array}{c}2.4 \\
(0.4)\end{array}$ & $\begin{array}{c}0.003 \\
(0.002-0.005)\end{array}$ & 120 & $\begin{array}{c}2.2 \\
(0.5)\end{array}$ & $\begin{array}{c}0.020 \\
(0.014-0.032)\end{array}$ \\
\hline Deltamethrin & 180 & $\begin{array}{c}3.9 \\
(0.6)\end{array}$ & $\begin{array}{c}0.004 \\
(0.003-0.005)\end{array}$ & 300 & $\begin{array}{c}2.7 \\
(0.4)\end{array}$ & $\begin{array}{c}0.0003 \\
(0.0002-0.0004)\end{array}$ & 250 & $\begin{array}{c}2.7 \\
(0.5)\end{array}$ & $\begin{array}{c}0.004 \\
(0.003-0.005)\end{array}$ \\
\hline Fenfluthrin & 150 & $\begin{array}{c}4.7 \\
(0.9)\end{array}$ & $\begin{array}{c}0.11 \\
(0.09-0.13)\end{array}$ & 200 & $\begin{array}{c}2.7 \\
(0.5)\end{array}$ & $\begin{array}{c}0.015 \\
(0.011-0.019)\end{array}$ & 200 & $\begin{array}{c}4.7 \\
(0.9)\end{array}$ & $\begin{array}{c}0.024 \\
(0.020-0.029)\end{array}$ \\
\hline Malathion & 180 & $\begin{array}{c}2.3 \\
(0.3)\end{array}$ & $\begin{array}{c}8.4 \\
(6.4-10)\end{array}$ & 260 & $\begin{array}{c}1.2 \\
(0.2)\end{array}$ & $\begin{array}{l}2.4 \\
(1.6-4.0)\end{array}$ & 140 & $\begin{array}{c}2.1 \\
(0.4)\end{array}$ & $\begin{array}{c}0.053 \\
(0.039-0.078)\end{array}$ \\
\hline Permethrin & 150 & $\begin{array}{l}4.0 \\
(0.7)\end{array}$ & $\begin{array}{c}0.067 \\
(0.055-0.081)\end{array}$ & 150 & $\begin{array}{l}5.2 \\
(1.0)\end{array}$ & $\begin{array}{c}0.048 \\
(0.043-0.055)\end{array}$ & 150 & $\begin{array}{c}6.1 \\
(1.1)\end{array}$ & $\begin{array}{c}0.043 \\
(0.037-0.050)\end{array}$ \\
\hline Propoxur & 120 & $\begin{array}{l}1.9 \\
(0.4)\end{array}$ & $\begin{array}{c}0.21 \\
(0.13-0.30)\end{array}$ & 120 & $\begin{array}{c}4.7 \\
(0.9)\end{array}$ & $\begin{array}{c}0.19 \\
(0.15-0.23)\end{array}$ & 210 & $\begin{array}{c}3.3 \\
(0.5)\end{array}$ & $\begin{array}{c}0.04 \\
\langle 0.03-0.05\rangle\end{array}$ \\
\hline Pyrethrins & 220 & $\begin{array}{c}9.3 \\
(1.3)\end{array}$ & $\begin{array}{c}0.38 \\
(0.35-0.40)\end{array}$ & 130 & $\begin{array}{c}1.7 \\
(0.4)\end{array}$ & $\begin{array}{c}0.012 \\
(0.008-0.020)\end{array}$ & 180 & $\begin{array}{c}4.4 \\
(0.6)\end{array}$ & $\begin{array}{c}0.14 \\
(0.12-0.16)\end{array}$ \\
\hline
\end{tabular}

${ }^{a} \mathrm{LD}_{\overline{5} 0}$ expressed as $\mu \mathrm{g}$ per cockroach.

sistant strains by topical application are shown in Table 2 , and resistance ratios $\left(\mathrm{LD}_{50}\right.$ resistant strain/ $\mathrm{LD}_{50}$ susceptible strain) are presented in Fig. 2. The Rutgers strain was highly resistant ( $>10$-fold) to bendiocarb and moderately resistant (3- to 10fold) to malathion, chlorpyrifos, propoxur, and pyrethrins. Although the resistance level at the $L_{50}$ was only moderate for malathion, the dose-response line was very flat (Table 2), and resistance was much higher at the $\mathrm{LD}_{95}$, suggesting considerable heterogeneity in this strain. The Kenly strain was highly resistant ( $>10$-fold) to bendiocarb, propoxur, and malathion and had moderate levels of resistance to all the other compounds tested. Based on overlap of $95 \%$ confidence intervals, the Ectiban-R strain was highly resistant to all three pyrethroids and pyrethrins, but not to any of the other insecticides. This result is consistent with previous studies on this strain, in which the mechanism of resistance was identified as a $k d r$-type (Scott \& Matsumura 1981, 1983).

The resistance levels of large nymphs of the Rutgers or Kenly strains to 12 insecticides by residual exposure are shown in Table 3 . Both strains exhibited very high levels ( $>50$-fold) of resistance to bendiocarb and malathion. The Kenly strain was also highly resistant to pyrethrins. Resistance levels probably sufficiently high to limit control were also noted for propoxur in the Kenly strain and diazinon in the Rutgers strain.

A comparison of results for the residual (Table 3) and topical (Fig. 2) tests indicated some similarities in the patterns of resistance. Resistance to malathion, bendiocarb, and pyrethrins was highest in the Kenly strain by both methods. The high level of bendiocarb resistance was also detected by both methods. The lower level of malathion resistance in the Rutgers strain by topical application compared with residue testing probably reflects a loss of resistance in this strain because it has not been selected for several generations since it was received at Cornell.

The large difference in the pyrethrins resistance noted between the Kenly and Rutgers strains by

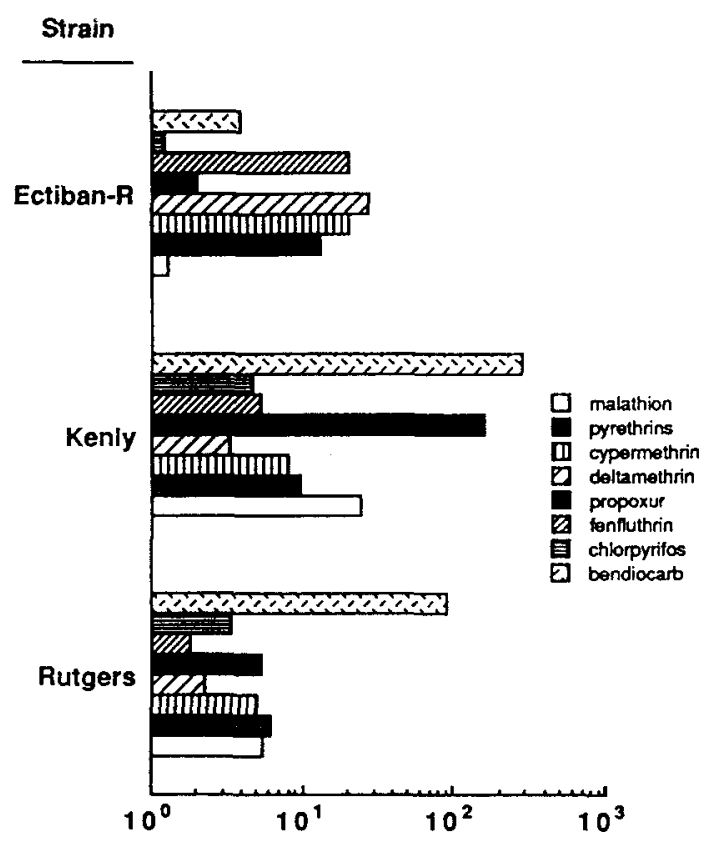

\section{Reslstance Ratlo}

Fig. 2. Levels of resistance to 10 insecticides in three insecticide-resistant strains of German cockroach. 
Table 2. Toxicity of eight insecticides to three resistant strains of German cockroach by topical application

\begin{tabular}{|c|c|c|c|c|c|c|c|c|c|}
\hline \multirow[b]{2}{*}{ Treatment } & \multicolumn{3}{|c|}{ Rutgers } & \multicolumn{3}{|c|}{ Kenly } & \multicolumn{3}{|c|}{ Ectiban-R } \\
\hline & $n$ & $\begin{array}{c}\text { Slope } \\
( \pm \mathrm{SE})\end{array}$ & $\begin{array}{c}\mathrm{LD}_{50^{a}} \\
(95 \% \mathrm{CI})\end{array}$ & $n$ & $\begin{array}{l}\text { Slope } \\
\text { ( } \pm \text { SE) }\end{array}$ & $\begin{array}{c}\mathrm{LD}_{50^{a}} \\
(95 \% \mathrm{CI})\end{array}$ & $n$ & $\begin{array}{c}\text { Slope } \\
\text { ( } \pm \text { SE) }\end{array}$ & $\begin{array}{c}\mathrm{LD}_{50}{ }^{a} \\
(95 \% \mathrm{CI})\end{array}$ \\
\hline Bendiocarb & 180 & $\begin{array}{c}0.7 \\
(0.2)\end{array}$ & $\begin{array}{l}32 \\
(13-143)\end{array}$ & & - & $\begin{array}{l}>100 \\
(47 \%)^{b}\end{array}$ & 200 & $\begin{array}{c}0.6 \\
(0.2)\end{array}$ & $\begin{array}{c}1.8 \\
(0.2-5.6)\end{array}$ \\
\hline Bendiocarb + PBO & 150 & $\begin{array}{c}2.0 \\
(0.4)\end{array}$ & $\begin{array}{c}0.81 \\
(0.55-1.2)\end{array}$ & 120 & $\begin{array}{c}1.3 \\
\quad(0.5)\end{array}$ & $\begin{array}{c}5.5 \\
(2.3-8.9)\end{array}$ & - & - & - \\
\hline Bendiocarb + DEF & 150 & $\begin{array}{c}2.6 \\
(0.5)\end{array}$ & $\begin{array}{c}0.11 \\
(0.08-0.14)\end{array}$ & 150 & $\begin{array}{c}1.6 \\
(0.4)\end{array}$ & $\begin{array}{c}0.32 \\
(0.21-0.47)\end{array}$ & - & - & - \\
\hline Chlorpyrifos & 150 & $\begin{array}{c}3.7 \\
(0.6)\end{array}$ & $\begin{array}{c}0.89 \\
(0.71-1.1)\end{array}$ & 200 & $\begin{array}{c}6.4 \\
(1.0)\end{array}$ & $\begin{array}{c}1.2 \\
(1.1-1.4)\end{array}$ & 220 & $\begin{array}{c}6.3 \\
(0.9)\end{array}$ & $\begin{array}{c}0.32 \\
(0.30-0.35)\end{array}$ \\
\hline Cypermethrin & 150 & $\begin{array}{c}2.4 \\
(0.5)\end{array}$ & $\begin{array}{c}0.24 \\
(0.18-0.32)\end{array}$ & 150 & $\begin{array}{l}2.6 \\
(0.5)\end{array}$ & $\begin{array}{c}0.38 \\
(0.27-0.48)\end{array}$ & 150 & $\begin{array}{c}2.8 \\
(0.5)\end{array}$ & $\begin{array}{c}0.97 \\
(0.73-1.28)\end{array}$ \\
\hline Cypermethrin + PBO & - & - & - & - & - & - & 120 & $\begin{array}{c}4.2 \\
(0.7)\end{array}$ & $\begin{array}{c}0.06 \\
(0.05-0.08)\end{array}$ \\
\hline Cypermethrin + DEF & - & - & - & - & - & - & 150 & $\begin{array}{c}2.9 \\
(0.5)\end{array}$ & $\begin{array}{c}0.42 \\
(0.32-0.56)\end{array}$ \\
\hline Deltamethrin & 350 & $\begin{array}{c}2.2 \\
(0.2)\end{array}$ & $\begin{array}{c}0.0009 \\
(0.007-0.011)\end{array}$ & 370 & $\begin{array}{c}2.5 \\
(0.2)\end{array}$ & $\begin{array}{c}0.013 \\
(0.011-0.015)\end{array}$ & 190 & $\begin{array}{c}2.8 \\
(0.4)\end{array}$ & $\begin{array}{c}0.11 \\
(0.09-0.14)\end{array}$ \\
\hline Fenfluthrin & 150 & $\begin{array}{c}3.8 \\
(0.6)\end{array}$ & $\begin{array}{c}0.20 \\
(0.16-0.23)\end{array}$ & 150 & $\begin{array}{c}3.1 \\
(0.6)\end{array}$ & $\begin{array}{c}0.57 \\
(0.45-0.69)\end{array}$ & 150 & $\begin{array}{c}8.9 \\
(1.7)\end{array}$ & $\begin{array}{c}2.2 \\
(2.0-2.4)\end{array}$ \\
\hline Malathion & 270 & $\begin{array}{c}0.6 \\
(0.1)\end{array}$ & $\begin{array}{l}45 \\
(24-99)\end{array}$ & 190 & $\begin{array}{c}1.2 \\
(0.2)\end{array}$ & $\begin{array}{l}203 \\
(130-385)\end{array}$ & 210 & $\begin{array}{c}1.6 \\
(0.3)\end{array}$ & $\begin{array}{c}11 \\
(7.8-15)\end{array}$ \\
\hline Malathion + PBO & 180 & $\begin{array}{c}1.1 \\
(0.2)\end{array}$ & $\begin{array}{c}1.6 \\
(0.9-3.2)\end{array}$ & - & - & - & - & - & - \\
\hline Malathion + DEF & 110 & $\begin{array}{c}2.7 \\
(0.5)\end{array}$ & $\begin{array}{c}0.18 \\
(0.14-0.26)\end{array}$ & - & - & - & - & - & - \\
\hline Propoxur & 180 & $\begin{array}{c}1.5 \\
(0.3)\end{array}$ & $\begin{array}{c}1.1 \\
(0.7-1.6)\end{array}$ & 400 & $\begin{array}{c}1.2 \\
(0.2)\end{array}$ & $\begin{array}{l}33 \\
(25-46)\end{array}$ & 120 & $\begin{array}{l}1.6 \\
(0.4)\end{array}$ & $\begin{array}{c}0.41 \\
(0.28-0.71)\end{array}$ \\
\hline Propoxur + PBO & - & - & - & 160 & $\begin{array}{c}2.9 \\
(0.5)\end{array}$ & $\begin{array}{c}1.0 \\
(0.8-1.3)\end{array}$ & - & $\ldots$ & - \\
\hline Propoxur + DEF & - & - & - & 200 & $\begin{array}{c}1.9 \\
(0.3)\end{array}$ & $\begin{array}{c}0.35 \\
(0.26-0.47)\end{array}$ & - & - & 一 \\
\hline Pyrethrins & 160 & $\begin{array}{c}1.6 \\
(0.3)\end{array}$ & $\begin{array}{l}2.3 \\
(1.6-3.1)\end{array}$ & 140 & $\begin{array}{c}2.2 \\
(0.4)\end{array}$ & $\begin{array}{c}3.6 \\
(2.7-4.9)\end{array}$ & 120 & $\begin{array}{c}4.0 \\
(0.8)\end{array}$ & $\begin{array}{c}5.1 \\
(4.1-6.2)\end{array}$ \\
\hline Pyrethrins + PBO & - & - & - & 180 & $\begin{array}{c}1.8 \\
(0.3)\end{array}$ & $\begin{array}{c}0.09 \\
(0.07-0.13)\end{array}$ & - & - & - \\
\hline Pyrethrins + DEF & -- & - & - & 140 & $\begin{array}{l}2.1 \\
(0.4)\end{array}$ & $\begin{array}{c}1.0 \\
(0.7-1.4)\end{array}$ & - & - & - \\
\hline
\end{tabular}

${ }^{a} \mathrm{LD}_{50}$ expressed as $\mu \mathrm{g}$ per cockroach.

${ }^{b}$ Percentage mortality at $100 \mu \mathrm{g} / \mathrm{jar}$.

residual bioassay (Table 3) was not observed by topical application. In addition, the Rutgers strain had a resistance ratio of $>6$ for pyrethrins by the topical application method and a resistance ratio of only 1.3 by the residue method, again suggesting that the two methods may involve different physiological systems or resistance mechanisms. Obviously, results from the two methods cannot always be compared directly (Scott et al. 1986). The $\mathrm{LT}_{50}$ (residue) method is invaluable as a means to monitor insecticide resistance because it allows the accumulation of large amounts of data quickly. The $\mathrm{LD}_{50}$ (topical) method may be more appropriate for other toxicological tests because the amount applied is precisely known.

To investigate possible mechanisms of resistance to those insecticides to which one or more strains displayed high levels of resistance, we used the synergists PBO and DEF. The effect of $\mathrm{PBO}$ and DEF on the level of resistance is shown in Fig. 3. Resistance to cypermethrin in the Ectiban-R strain
Table 3. Resistance levels of two strains of German cockroach to 12 insecticides by residual exposure

\begin{tabular}{lcc}
\hline & \multicolumn{2}{c}{ Resistance ratio } \\
\cline { 2 - 3 } Insecticide & Kenly & Rutgers \\
\hline Acephate & 1.1 & 0.9 \\
Allethrin & 1.5 & 1.5 \\
Bendiocarb & $>70$ & $>60$ \\
Chlorpyrifos & 1.8 & 1.5 \\
Diazinon & 2.2 & 3.6 \\
Fenvalerate & 0.9 & 0.9 \\
Flucythrin & 1.1 & 1.1 \\
Malathion & $>60$ & $>70$ \\
Permethrin & 1.0 & 0.8 \\
Phenothrin & 1.3 & 1.0 \\
Propoxur & 6.1 & 1.4 \\
Pyrethrins & $>240$ & 1.3 \\
\hline
\end{tabular}

${ }^{a}$ Data from Cochran (1989) 


\section{Insecticide Strain}

\section{Bendiocarb}

Pyrethrins

Propoxur

\section{Bendiocarb \\ Malathion}

Cypermethrin
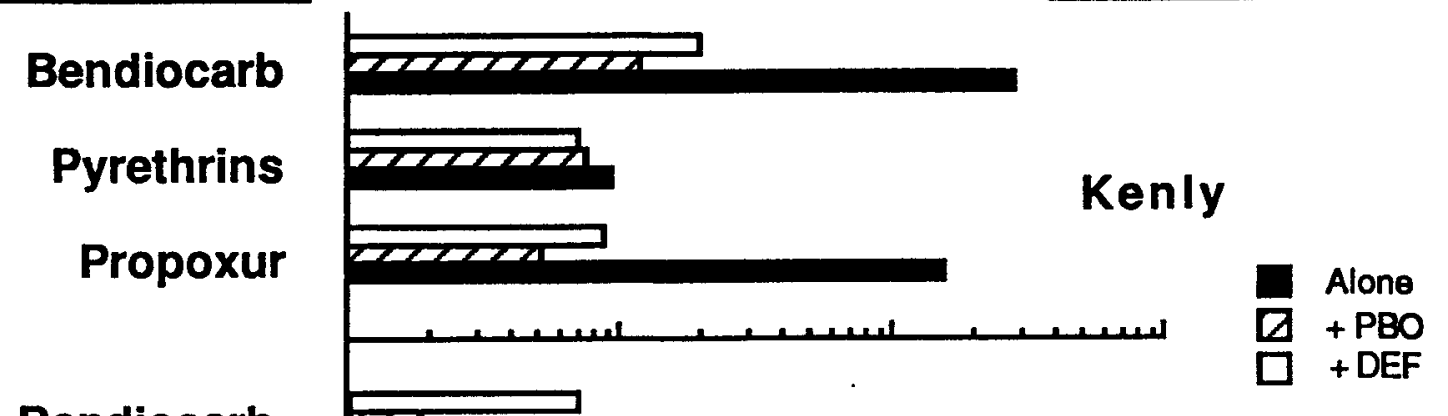

Kenly

Rutgers

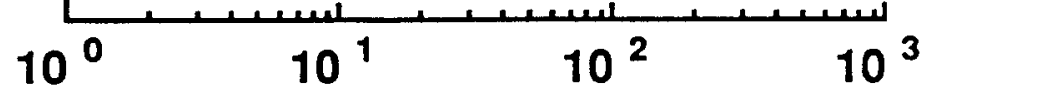

Resistance Ratio

Fig. 3. Effect of the synergists PBO and DEF on resistance in three strains of the German cockroach.

was unaffected by $\mathrm{PBO}$ and DEF, suggesting that resistance is not the result of increased metabolic detoxification and supporting the evidence for a $k d r$-type resistance in this strain (Scott \& Matsumura 1981, 1983). The 100 -fold resistance to propoxur in the Kenly strain was reduced to 15- and 7 -fold with DEF and $\mathrm{PBO}$, respectively, suggesting that hydrolytic and oxidative detoxification are, at least in part, responsible for this resistance. Similarly, bendiocarb resistance in both the Kenly and Rutgers strains was partially suppressed by PBO or $D E F$, suggesting that oxidative and hydrolytic detoxification are at least partly involved in the resistance. Malathion resistance in the Rutgers strain was suppressed with $\mathrm{PBO}$, but not DEF, suggesting that oxidative metabolism may be the mechanism of resistance in this strain. Pyrethrins resistance in the Kenly strain was largely unaffected by either synergist. This result is in sharp contrast with a previous report of a time-variable residual contact bioassay in which resistance to pyrethrins was reduced from $>80$ - to 1.3 -fold with PBO (Cochran 1987). With the time-mortality method, immobilization (end-point in this bioassay) of the susceptible strain is very rapid because a relatively high concentration is used. Therefore, the only physiological processes involved in the poisoning of susceptible cockroaches would be cuticular penetration and interaction with the target site (Sawicki 1962, Ford \& Pert 1974, Scott \& Matsumura 1983,
Scott \& Georghiou 1984). Thus, addition of a synergist that blocks metabolism would have little or no effect on the $\mathrm{LT}_{50}$ of the susceptible strain. However, in the resistant strain longer times are needed for immobilization, and at these longer times metabolism is important in the poisoning process (Sawicki 1962, Ford \& Pert 1974, Scott \& Matsumura 1983, Scott \& Georghiou 1984). Therefore, synergism can be observed only in the resistant strain, giving the illusion that the synergist was reducing the level of resistance. Alternatively, the two different methods of application may affect different physiological systems, resistance mechanisms, or both.

Brattsten (1987) suggested that if a naturally occurring detoxification system is relatively abundant, it may predispose an insect species to develop resistance by this mechanism. Our results do not support this idea, however. In the case of malathion, for example, the susceptible strain possesses a highly efficient DEF-suppressible (i.e., hydrolase) metabolism. Yet results on the malathion-resistant strain (Rutgers) suggest that resistance is not due to hydrolases because DEF did not affect resistance levels. A similar pattern was noted for resistance to pyrethrins in the Kenly strain. Conversely, resistance to propoxur in the Kenly strain was suppressed with DEF and $\mathrm{PBO}$, but these synergists had only a 1.1-and 5.2-fold effect on the susceptible strain, respectively. 


\section{Acknowledgment}

The authors wish to thank N. Liu (Cornell University) for technical assistance, F. Matsumura (University of California, Davis) for supplying the CSMA and Ectiban- $R$ cockroaches, and $R$. Roush (Cornell University) for valuable comments. This study was supported in part by a grant from the U.S. Department of Agriculture and Hatch Project 139414.

\section{References Cited}

Brattsten, L. B. 1987. Metabolic insecticide defenses in the boll weevil compared to those in a resistanceprone species. Pestic. Biochem. Physiol. 27: 1-12.

Cochran, D. G. 1982. German cockroach resistance: new modes of action could stalemate resistance. Pest. Contr. 50: 16-20.

1987. Effects of synergists on bendiocarb and pyrethrins resistance in the German cockroach (Dictyoptera: Blattellidae). J. Econ. Entomol. 80: 728-732.

1989. Monitoring for insecticide resistance in fieldcollected strains of the German cockroach (Dictyoptera: Blattellidae). J. Econ. Entomol. 82: 336-341.

Ford, M. G. \& D. R. Pert. 1974. Time-dose-response relationships of pyrethroid insecticides with special reference to knockdown. Pestic. Sci. 5: 635-641.

Raymond, M. 1985. Présentation d'une programme Basic d'analyse log-probit pour micro-ordinateur. Cah. O.R.S.T.O.M. Ser. Entomol. Med. Parasitol. 23: 117121.
Rust, M. K. \& D. Reierson. 1978. Comparison of the laboratory and field efficacy of insecticides used for German cockroach control. J. Econ. Entomol. 71: 704708.

Sawieki, R. M. 1962. Insecticidal activity of pyrethrum extract and its four insecticidal constituents against house flies. III. Knock-down and recovery of flies treated with pyrethrum extract with and without piperonyl butoxide. J. Sci. Food Agric. 13: 283-291.

Scott, J. G. \& G. P. Georghiou. 1984. Influence of . temperature on knockdown, toxicity and resistance to pyrethroids in the house fly Musca domestica. Pestic. Biochem. Physiol. 21: 53-62.

Scott, J. G. \& F. Matsumura. 1981. Characteristics of a DDT-induced case of cross-resistance to permethrin in Blattella germanica. Pestic. Biochem. Physiol. 16: 21-27.

1983. Evidence for two types of toxic actions of pyrethroids on susceptible and DDT-resistant German cockroaches. Pestic. Biochem. Physiol. 19: 141-150.

Scott, J. G., S. B. Ramaswamy, F. Matsumura \& K. Tanaka. 1986. Effect of method of application on resistance to pyrethroid insecticides in Blattella germanica (Orthoptera: Blattellidae). J. Econ. Entomol. 79: 571-575.

Telford, J. N. \& F. Matsumura. 1970. Dieldrin binding in subcellular nerve components of cockroaches. An electron microscopic and autoradiographic study. J. Econ. Entomol. 63: 795-800.

Received for publication 12 September 1989; accepted 23 February 1990 